\title{
Effect of inorganic and Rhizobium fertilizer levels on soil physco-chemical properties under pea (Pisum sativum L.) cultivation
}

\section{HEMRAJ MEENA AND NARENDRA SWAROOP}

MEMBERS OF RESEARCH FORUM:
Corresponding author :
HEMRAJ MEENA, Department of Soil
Science, Allahabad School of
Agriculture, Sam Higginbottom
Institute of Agriculture, Technology
and Sciences, ALLAHABAD (U.P.)
INDIA
Email: hemraj3158@gmail.com

Co-authors :

NARENDRA SWAROOP, Department

of Soil Science, Allahabad School of Agriculture, Sam Higginbottom Institute of Agriculture, Technology and Sciences, ALLAHABAD (U.P.) INDIA

Email: narendraswaroop1958@gmail.com

\section{Summary}

Received : 02.06.2015; Revised : 05.11.2015; Accepted : 20.11.2015

A field experiment was conducted on effect of different levels of inorganic fertilizers and Rhizobium on soil properties with pea (Pisum sativum L.) during Rabi season 2013-14 at the Research farm of Soil Science, Allahabad. The experiment was laid out in Randomized Block Design with three replications, with $3 \times 3$ factorial RBD, on sandy loam soil sand 61.73 per cent, silt 20.12 per cent and clay 18.15 per cent (Inceptisol), consisted nine treatment it was observed that the best findings were reported for post harvest soil properties in treatment $\mathrm{T}_{8}$ $\mathrm{L}_{2} \mathrm{R}_{2}\left(\mathrm{~N}_{30} \mathrm{P}_{60} \mathrm{~K}_{40} \mathrm{~kg} \mathrm{ha}^{-1}\right.$ and $20 \mathrm{~g}$ Rhizobium $\mathrm{kg}^{-1}$ seed), organic carbon 0.62 per cent, available nitrogen $273.43 \mathrm{~kg} \mathrm{ha}^{-1}$, phosphorus $29.60 \mathrm{~kg} \mathrm{ha}^{-1}$, potassium, $165.99 \mathrm{~kg} \mathrm{ha}^{-1}$, pore space 50.54 per cent, bulk density $1.35 \mathrm{~g} \mathrm{~cm}^{-3}$, particle density $2.73 \mathrm{~g} \mathrm{~cm}^{-3}, \mathrm{pH} 7.64$ and $\mathrm{EC}$ at $25^{\circ} \mathrm{C}^{-} 0.25 \mathrm{dSm}$ ${ }^{1}$, respectively, and available nitrogen, phosphorus, organic carbon, pore space were found to be significant, and available potassium, bulk density, particle density, $\mathrm{EC}, \mathrm{pH}$ were found to be non-significant. Adequate plant nutrient supply holds the key for improving the food grain production and sustaining soil fertility.

Key words : Inorganic fertilizer, Rhizobium, Soil properties, Pea

How to cite this article : Meena, Hemraj and Swaroop, Narendra (2015). Effect of inorganic and Rhizobium fertilizer levels on soil physco-chemical properties under pea (Pisum sativum L.) cultivation. Asian J. Soil Sci., 10(2) : 271-275. 